\title{
Quantitative Serum Proteomics of Tryptophan Nutrition Using Bi-directional Heavy Oxygen Labeling with a RuBisCO Internal Standard
}

\author{
Amanda M. Cooksey ${ }^{1,2, \#, *}$, Alejandro Corzo ${ }^{3, \#}$, Marek D. Koter ${ }^{1}$ and Shane C. Burgess ${ }^{1,2,4}$
}

${ }^{1}$ Department of Basic Sciences, College of Veterinary Medicine, Mississippi State University, Mississippi State, MS
39762; ${ }^{2}$ Institute for Digital Biology, College of Veterinary Medicine, Mississippi State University, Mississippi State, MS
39762; ${ }^{3}$ Department of Poultry Science, Mississippi State University, Mississippi State, MS 39762 and ${ }^{4}$ Missipissippi
Agricultural and Forestry Experiment Station, Mississippi State University, Mississippi State, MS, 39762, USA

Abstract: Tryptophan plays an important role in vertebrate metabolism as not only a building block of proteins, but also as a precursor of serotonin, melatonin, niacin and kynurenines, which influence immune tolerance. Here we use an animal paradigm and quantitative serum proteomics to model tryptophan deficiency. We applied bidirectional $\mathrm{H}_{2}{ }^{16 / 18} \mathrm{O}$ labeling to serum proteins from chickens fed either a tryptophan-deficient or- adequate diet and used the plant protein $\mathrm{RuBisCO}$ as an internal standard. The proteins were trypsin digested and processed by 2-dimensional liquid chromatography electrospray ionization tandem mass spectrometry (2D LC ESI MS ${ }^{2}$ ). The resulting mass spectra were analyzed using the SEQUEST algorithm and the ProteinMapper program to identify proteins that had increased or decreased expression. We identified 4161 proteins labeled bidirectionally, of which 46 were increased and 90 decreased $(\sim 3 \%)$. Using Ingenuity Pathways Analysis (IPA) software, we found that a tryptophan nutritional deficiency may affect not only the immune and neurological systems, but our modeling also suggests that it may be important in cancer, optic atrophy and cardiomyopathy.

Key Words: Isotope labeling, Ingenuity, modeling, systems biology, quantitation, diet, deficiency, biomarkers.

\section{INTRODUCTION}

Tryptophan is one of the nine essential amino acids that cannot be synthesized de novo and must be present in human diets. Poultry, fish, soybeans and red meats are excellent sources of dietary tryptophan. Human tryptophan deficiency still occurs in countries where malnutrition is due to scarcity and tryptophan-related diseases result from deficiencies. However, first world countries, where food excess is seen as a problem, may now also be experiencing the effects of dietary tryptophan both in old age diseases such as Alzheimer's and in behavior. Tryptophan is also an essential amino acid for production and companion animals and has been linked to some economic and behavioral problems. Tryptophan is important as one of the limiting amino acids in protein metabolism and is critical as a metabolic intermediate. Tryptophan deficiency is known to affect the immune and neurological systems.

Tryptophan is a precursor of serotonin and melatonin. Serotonin is a monoamine neurotransmitter involved in a number of behavioral and psychological processes including appetite and mood. Obesity, a growing problem in the US may be linked to serotonin, which regulates not only appetite but also influences the selection of major food constituents [1]. Low brain serotonin is associated with aggressive behavior and tryptophan has some therapeutic effect in pathologically aggressive patients [2]. Tryptophan also seems to have

*Address correspondence to this author at the Department of Basic Sciences, College of Veterinary Medicine, Mississippi State University, Mississippi State, MS 39762, USA; E-mail: Cooksey@cvm.msstate.edu

"These authors contributed equally to this work. an antidepressant effect in mild-to-moderate clinical depression [3]. Serotonin is converted to melatonin via 5-HTNacetylase and 5-hydroxyindol O-methyltransferase. Melatonin production is regulated by light and is involved in the regulation of circadian rhythms. Reduced melatonin may also be a contributing factor to the increased cancer risk of night shift workers [4]. Furthermore, tryptophan as a precursor of both serotonin and melatonin, reduces sleep latency and promotes feelings of drowsiness and fatigue [5]. Conversely, increased serum tryptophan enhances the intoxication effects of both barbiturates and alcohol [6]. Tryptophan is also a precursor of vitamin B3 (niacin) and its deficiency in combination with low dietary niacin causes pellagra, a disease commonly found in malnourished populations. Tryptophan is also important to immunity directly. Kynurenines, which are important in immune tolerance [7], are also derived from tryptophan via indolamine 2,3-dioxygenase (IDO). IDO production of kynurenines inhibits T-cell proliferation and T-cell antigen priming as well as inducing CD8+ T-cell anergy and apoptosis of T-helper 1 cells, all contributing to immune tolerance $[8,9]$. Kynurenine molecules also reduce the symptoms of autoimmune diseases such as colitis, experimental autoimmune encephalomyelitis, autoimmune diabetes and experimental asthma [10-12].

Here we describe for the first time a bidirectional quantitative isotope labeling $\left(\mathrm{H}_{2}{ }^{16 / 18} \mathrm{O}\right)$ proteomics approach combined with a novel internal standard (RuBisCO) to describe biomarkers in serum of tryptophan sufficiency/deficiency. Serum is ideal for proteomics because it can contain proteins expressed anywhere in the body and is easily sampled. ${ }^{18} \mathrm{O}$ labeling is a simple and convenient stable isotope labeling strategy requiring only the presence of $\mathrm{H}_{2}{ }^{18} \mathrm{O}$ and no other 
reagents, additional labeling, or purification steps. Peptides are labeled at their $\mathrm{C}$-termini during enzymatic digestion through the enzyme-catalyzed incorporation of oxygen [13]. However, ${ }^{18} \mathrm{O}$ labeling efficiency is limited by the purity of $\mathrm{H}_{2}{ }^{18} \mathrm{O}$.

Although mice and pigs are commonly used as animal models for amino acid nutrition studies, we have used the chicken. Chickens, as our de facto avian biomedical model occupy a unique and informative evolutionary niche [14]. Chickens are economically important and with extremely well-regulated nutrition about which much is known. We identified 136 proteins to be differentially expressed in tryptophan deficiency. These proteins all have potential, either by themselves or in groups, as biomarkers for human and animal tryptophan deficiency. Furthermore, we used our dataset as a basis for systems biology modeling. This computational modeling suggests molecular perturbations due to tryptophan deficiency are involved in not only autoimmune and neurological disorders but also other disease processes.

\section{MATERIALS AND METHODOLOGY}

\section{Chickens and Experimental Design}

One hundred ninety six one-day-old Ross $\times$ Ross-508 slowfeathering male chicks (Aviagen North America, Huntsville, AL, USA) vaccinated against Marek's and Newcastle disease viruses (Merial Ltd, GA, USA) were randomly allocated to 14 floor pens $(0.9 \times 1.2 \mathrm{~m})$ and fed on tryptophan adequate $(2.1 \mathrm{mg} / \mathrm{kg} ; 7$ pens $)$ or depleted $(1.3 \mathrm{mg} / \mathrm{kg} ; 7$ pens $)$ diets fed ad libitum. Temperature was set for the birds to achieve thermoneutrality throughout the study [15]. Ingredients used in the experimental diets were analyzed for amino acids by HPLC after acid hydrolysis [16]. Upon analyses, the nutrient matrix of the feed ingredients used was updated and the test diet was then formulated using linear programming that solved for energy, amino acids, mineral and vitamin needs that satisfied optimal growth. At 20 days-of-age, blood was collected into plain tubes; after transferring to the laboratory, the clots were separated from serum by centrifugation $(12,200 \mathrm{x} \mathrm{g} ; 10 \mathrm{~min})$. Serum $(100 \mu \mathrm{l})$ from each chicken was collected and randomly allocated to one of three pools for each treatment group. All six pools were then stored at $80^{\circ} \mathrm{C}$.

\section{Depletion of Albumin and IgG from Serum}

Depletion of albumin and IgG was done by immunoprecipitation using protein G-agarose beads. Protein G-agarose beads (Fluka; $10 \mu \mathrm{l}$ hydrated resin) were mixed with $1 \mathrm{ml}$ $(57 \mathrm{mg} / \mathrm{ml})$ anti-chicken albumin IgG (Accurate Chemical and Scientific Corporation, Westbury, NY) and incubated for $2 \mathrm{hr}$ at room temperature on a rocking platform. The beads and bound anti-albumin $\operatorname{IgG}$ were pelleted by centrifugation $(12000 \mathrm{x} g ; 2 \mathrm{~min})$ and resuspended in phosphate buffered saline (PBS; $300 \mu \mathrm{l}$ ). To deplete serum albumin, $50 \mu \mathrm{l}$ of this solution was added to $200 \mu 1$ serum and incubated on a rocking platform $\left(12 \mathrm{~h} ; 4^{\circ} \mathrm{C}\right)$ then centrifuged $(12000 \mathrm{x} \mathrm{g}, 2 \mathrm{~min}$, $\left.4^{\circ} \mathrm{C}\right)$. The beads and bound albumin were pelleted by centrifugation $\left(12000 \mathrm{x} \mathrm{g} ; 2 \mathrm{~min} ; 4^{\circ} \mathrm{C}\right)$ and supernatants were collected. To deplete IgG, $5 \mu$ protein G-agarose beads were added to each tube of supernatant. These suspensions were first incubated on a rocking platform $\left(4 \mathrm{~h} ; 4^{\circ} \mathrm{C}\right)$ then centrifuged $\left(12000 \mathrm{x} \mathrm{g}, 2 \mathrm{~min}, 4^{\circ} \mathrm{C}\right)$. Supernatants, depleted of albumin and IgG, were collected and serum proteins were quantified using the 2-D Quant Kit (GE Healthcare, San Francisco, USA).

\section{Ribulose-1,5-Bisphosphate (RuBisCO) Internal Standard}

Carboxylase/Oxygenase

Internal standards allow for the normalization of data to ensure accurate quantitative comparisons. Ideally, internal standards should be easily distinguished from the experimental samples. This presents an obstacle for serum proteomics considering the complexity of the serum proteome and sequence conservation among species. Here, we used the large and small subunits (NCBI accession numbers P00870 and CAB88737, respectively) of Spinacia oleracea (domestic spinach) RuBisCO (Sigma-Aldrich, St. Louis, MO), a plant enzyme involved in carbon fixation, as an internal standard. Spinach RuBisCO has no sequence similarity to any vertebrate gene except for an unknown mouse protein (AAH38257.1) [17]. However, AAH38257.1 does not BLAST to the mouse, or any other vertebrate, genome sequence. We believe that AAH38257.1 is an EST sequencing anomaly, potentially due to contamination, or an error in the database.

\section{${ }^{18}$ O Labeling Efficiency}

Trypsin digestion catalyzes incorporation of two oxygen molecules to the c-terminus of peptides derived during protein cleavage and this has been taken advantage of to introduce a 4 Da change in mass for proteomics [13]. ${ }^{18} \mathrm{O}$ labeling is simple and convenient, requiring no reagents or additional purification steps other than $\mathrm{H}_{2}{ }^{18} \mathrm{O}$. However, ${ }^{18} \mathrm{O}$ labeling efficiency is limited by the purity of $\mathrm{H}_{2}{ }^{18} \mathrm{O}$. To establish ${ }^{18} \mathrm{O}$ labeling efficiency in our hands, we trypsin-digested (molecular biology grade trypsin; Promega Corporation, Madison, WI; $50: 1$ protein:trypsin $\{\mathrm{w} / \mathrm{w}\} ; 24 \mathrm{~h} ; 37^{\circ} \mathrm{C}$ ) a $1: 1: 1$ molar mixture of BSA (Sigma-Aldrich), horse cytochrome C (Sigma-Aldrich) and hen egg lysozyme (Sigma-Aldrich) in either $\mathrm{H}_{2}{ }^{16} \mathrm{O}$ or $\mathrm{H}_{2}{ }^{18} \mathrm{O}\left(95 \%{ }^{18} \mathrm{O}\right.$; Medical Isotopes, Inc. Pelham, NH, USA). Trypsin digestion was stopped by addition of acetic acid $(2 \mu \mathrm{l})$. The resulting peptides were combined in a 1:1 ratio and then analyzed by $1 \mathrm{D}$ LC ESI MS ${ }^{2}$ (see below). Mass spectrometry analysis of serum proteins requires the maximal peptide coverage afforded in a "full scan" mode (terminology used by the mass spectrometer manufacturer: ThermoElectron Corporation; San Jose, CA, USA). However, protein quantification is aided by the much more detailed information obtained when samples are run in a "zoom scan" mode. To determine if quantitative analysis of a serum proteome would be possible without compromising protein coverage, the number of peptides from BSA, cytochrome c and lysozyme were analyzed using both "full" and "zoom" scan modes; this resulted in 338 and 78 quantifiable peptides respectively. Thus, all mass spectrometry analysis was carried out using full scan. We identified pairs of precursor ions with a +4 amu difference (Fig. 1) and calculated ${ }^{18} \mathrm{O}$ labeling efficiency of $86 \%$ by comparing the number of heavy peptides to the number of light peptides.

\section{Serum Analysis Using RuBisCO Internal Standard and ${ }^{18}$ O Labeling}

Because of the ${ }^{18} \mathrm{O}$ inefficiency we did bidirectional labeling for the experiment itself (i.e. the trypsin adequate and 
inadequate samples were labeled in triplicate with ${ }^{18} \mathrm{O}$ and ${ }^{16} \mathrm{O}$ respectively and vice-versa). Two hundred $\mu \mathrm{g}$ of serum protein and $100 \mathrm{pM}$ of RuBisCO, were combined. Samples were diluted in ammonium bicarbonate $(0.1 \mathrm{M} ; 60 \mu \mathrm{l})$, reduced using dithiothreitol $\left(5 \mathrm{mM} ; 5 \mathrm{~min} ; 65^{\circ} \mathrm{C}\right)$ and alkylated using iodoacetamide $\left(10 \mathrm{mM} ; 30 \mathrm{~min} ; 30^{\circ} \mathrm{C}\right)$, all in $\mathrm{H}_{2}{ }^{16} \mathrm{O}$ or $\mathrm{H}_{2}{ }^{18} \mathrm{O}$ as required. To remove $\mathrm{H}_{2}{ }^{16} \mathrm{O}$ all samples were then frozen $\left(-80^{\circ} \mathrm{C} ; 15 \mathrm{~min}\right)$ and lyophilized (Freezone 6, Labconco Corporation, Kansas City, MO, USA; 4 hr). The proteins were then resuspended in $\mathrm{H}_{2}{ }^{16} \mathrm{O}$ or $\mathrm{H}_{2}{ }^{18} \mathrm{O}$ and trypsin digested as above. Following digestion the tryptophanadequate and tryptophan-deficient samples labeled with $\mathrm{H}_{2}{ }^{18} \mathrm{O}$ and $\mathrm{H}_{2}{ }^{16} \mathrm{O}$ respectively and vice versa were combined $1: 1$. This resulted in two triplicas: one containing $\mathrm{H}_{2}{ }^{16} \mathrm{O}$ tryptophan adequate and $\mathrm{H}_{2}{ }^{18} \mathrm{O}$ tryptophan deficient peptides and the other containing $\mathrm{H}_{2}{ }^{18} \mathrm{O}$ tryptophan adequate and $\mathrm{H}_{2}{ }^{16} \mathrm{O}$ tryptophan deficient peptides. These mixtures were then analyzed by $2 \mathrm{D}$ LC ESI MS ${ }^{2}$ (see below).

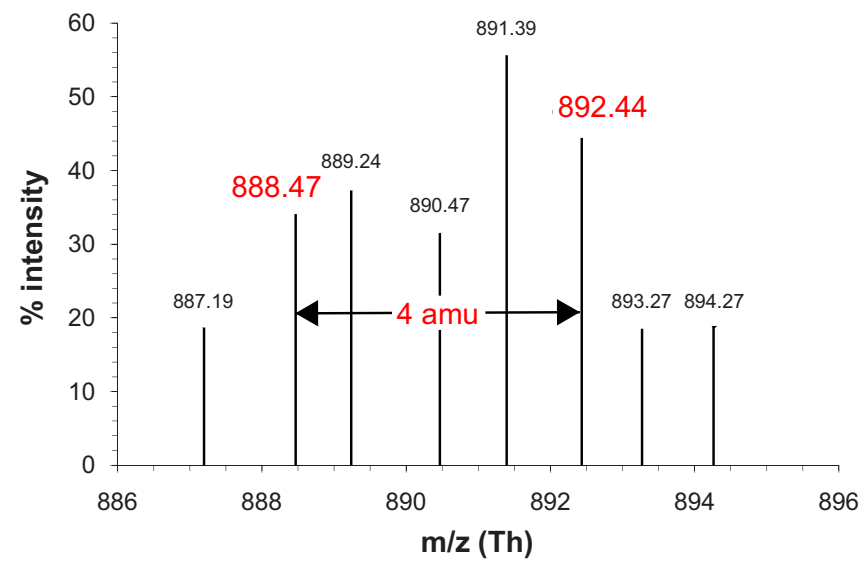

Fig. (1). Example spectrum of two full-scan precursor ions separated by $4 \mathrm{amu}\left(2 \mathrm{x}^{18} \mathrm{O}\right.$ atoms) identified as the same peptide by SEQUEST (peptide: ELDRDLK from protein XP_428275.1 PREDICTED: similar to bassoon; bassoon (presynaptic cytomatrix protein).

\section{Mass Spectrometry}

Peptides were desalted using a peptide macrotrap (Michrom Bioresources, Inc., Auburn, CA, USA) and eluted in a $95 \% \mathrm{ACN}, 0.01 \%$ TFA solution. Desalted peptides were dried in a vacuum centrifuge (ThermoElectron) and resuspended in $20 \mu \mathrm{l}$ of $0.1 \%$ formic acid. LC analysis was accomplished by SCX followed by RP LC coupled directly in line with ESI IT MS. Samples were loaded into a LC gradient ion exchange system containing a Thermo Separations P4000 quaternary gradient pump (ThermoElectron) coupled with a $0.32 \times 100 \mathrm{~mm}$ BioBasic SCX column. A flow rate of $3 \mu \mathrm{L} / \mathrm{min}$ was used for both SCX and RP columns. A salt gradient was applied in steps of $0,10,15,20,25,30,35,40$, $45,50,57,64,90$ and $700 \mathrm{mM}$ ammonium acetate in 5\% $\mathrm{ACN}, 0.1 \%$ formic acid and the resultant peptides loaded directly into the sample loop of a $0.18 \times 100 \mathrm{~mm}$ BioBasic C18 RP LC column of a ProteomeX workstation (Thermo Electron). The RP gradient used $0.1 \%$ formic acid in $\mathrm{ACN}$ and increased the ACN concentration in a linear gradient from $5 \%$ to $30 \%$ in $30 \mathrm{~min}$ and then $30 \%$ to $65 \%$ in $9 \mathrm{~min}$ followed by $95 \%$ for $5 \mathrm{~min}$ and $5 \%$ for $15 \mathrm{~min}$. The spectrum collection time was $59 \mathrm{~min}$ for every SCX step. The Deca LCQ IT mass spectrometer was configured to optimize the duty cycle length with the quality of data acquired by alternating between a single full MS scan followed by three tandem MS scans on the three most intense precursor masses (as determined by Xcalibur mass spectrometer software in real time) from the full scan. The collision energy was normalized to $35 \%$. Dynamic mass exclusion windows were set at $2 \mathrm{~min}$ and all of the spectra were measured with an overall mass/charge $(\mathrm{m} / \mathrm{z})$ ratio range of 300-1700 Th.

\section{Protein Identification}

Tandem mass spectra were used to search a chickenspecific protein database downloaded directly from the National Center for Biotechnology Institute (NCBI; 07/29/04) using TurboSEQUEST (Bioworks Browser 3.2; ThermoElectron). Spinach RuBisCO small and large subunit protein sequences were added to the chicken-specific database. Trypsin digestion was applied in silico to the modified database including mass changes due to cysteine carbamidomethylation, methionine oxidation and peptide $\mathrm{C}$-terminal heavy oxygen $\left({ }^{18} \mathrm{O}\right)$. Because albumin and $\operatorname{IgG}$ were depleted, the masses of albumin and IgG peptides determined by in silco digestion were eliminated from the search. The peptide (MS precursor ion) mass tolerance was set to $1.5 \mathrm{Da}$ and the fragment ion $\left(\mathrm{MS}^{2}\right)$ mass tolerance was set to $1.0 \mathrm{Da}$. Peptide matches were considered genuine if they were $\geq 6$ amino acids and consistent with described cross correlation (Xcorr) 1.5, 2.0, 2.5 for $+1,+2,+3$ charged ions respectively and $\Delta C_{n}$ values of $\geq 0.1[18]$.

\section{Data Analysis and Modeling}

For the 4161 proteins labeled bidirectionally, our ProteinMapper PERL program [19] was used to calculate $\Sigma X$ corr for each protein. To compensate for labeling inefficiency, $\Sigma$ Xcorr for ${ }^{18} \mathrm{O}$ labeled proteins were normalized with respect to ${ }^{16} \mathrm{O}$ labeled proteins, using $\mathrm{RuBisCO}$ as the standard. Finally, $\Sigma$ Xcorr of tryptophan adequate peptides was subtracted from that of tryptophan deficient peptides for each protein. Data were averaged across triplicas and proteins were grouped according to calculated confidence values $(\alpha=0.05)$. Proteins were identified as increased or decreased if the $95 \%$ confidence interval of the mean difference did not cross zero (Table 1). Proteins that we identified as increased or decreased were annotated using Gene Ontology (GO) for biological process using GOanna available from AgBase (www.agbase.msstate.edu) [20]. Biological process annotations for these proteins were grouped into more generalized categories using GOSlimViewer [20]. We used the Ingenuity Pathways Analysis software (IPA; Ingenuity Systems, Inc., Redwood City, CA) to model specific physiological processes affected by tryptophan deficiency exactly as described by the manufacturer (fold change $\geq 2$ ). However, IPA accepts only human, mouse or rat accession numbers. Before using IPA for modeling, chicken accession numbers were converted to their human orthologs. Accession numbers for which GOanna did not identify a human orthologs were manually converted to their human orthologs using NCBI's BLASTp (E-value $<0.000001)$. We then did IPA-based modeling using our orthologs data set and corresponding 
Table 1. Increased (A) and Decreased (B) Serum Proteins in Tryptophan Deficient, Relative to Control, Chickens (Mean Difference

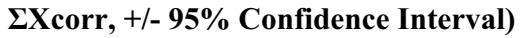

\begin{tabular}{|c|c|c|c|c|c|}
\hline & Accession \# & Protein Name & Mean Difference & $+95 \%$ Confidence & - 95\% Confidence \\
\hline \multirow{26}{*}{$\mathbf{A}$} & XP_422653 & Predicted similar to FERM, RhoGEF and pleckstrin domain & 16.8 & 30.6 & 3.1 \\
\hline & XP_423829 & Predicted similar to Mucolipin 1 & 13.7 & 20.7 & 6.8 \\
\hline & XP_425314 & Predicted similar to class I alpha chain & 11.4 & 17.4 & 5.5 \\
\hline & XP_418125 & Predicted similar to Peroxisome proliferator-activated receptor & 10.6 & 21.1 & 0.2 \\
\hline & XP_421797 & Predicted similar to chromosome 10 open reading frame 86 & 10.2 & 20.4 & 0.0 \\
\hline & XP_418349 & Predicted syndecan 2 & 9.0 & 15.5 & 2.5 \\
\hline & XP_422832 & Predicted similar to Hypothetical protein MGC57096 & 7.6 & 15.0 & 0.2 \\
\hline & XP_415660 & Predicted similar to hypothetical protein FLJ12735 & 7.6 & 15.1 & 0.0 \\
\hline & XP_419236 & Predicted similar to myosin binding protein- $\mathrm{H}$ & 7.5 & 14.9 & 0.1 \\
\hline & NP_989846 & interleukin 17 receptor D & 7.5 & 14.6 & 0.3 \\
\hline & XP_414300 & Predicted similar to Isoleucyl-tRNA synthetase, cytoplasmic & 7.3 & 14.0 & 0.7 \\
\hline & XP_413908 & Predicted similar to Butyrate-induced transcript 1 & 7.3 & 11.8 & 2.9 \\
\hline & XP_416476 & Predicted similar to Alpha-2-macroglobulin precursor & 7.0 & 12.3 & 1.7 \\
\hline & XP_426034 & Predicted similar to malin & 6.6 & 12.5 & 0.8 \\
\hline & XP_423230 & Predicted similar to NEDD9 interacting protein & 6.6 & 12.5 & 0.7 \\
\hline & XP_424714 & Predicted similar to Adipocyte-derived leucine aminopeptidase & 6.5 & 11.8 & 1.2 \\
\hline & XP_418200 & Predicted similar to BTB (POZ) domain containing 2 & 6.4 & 11.8 & 1.0 \\
\hline & XP_415810 & Predicted similar to OVCA1 $1=$ candidate tumor suppressor & 6.2 & 9.5 & 3.0 \\
\hline & XP_425552 & Predicted similar to claudin 14 & 5.8 & 10.6 & 1.0 \\
\hline & XP_417095 & Predicted similar to Regulatory factor $\mathrm{X}$-associated protein & 5.5 & 10.6 & 0.3 \\
\hline & NP_989989 & protein kinase, DNA-activated, catalytic polypeptide & 5.4 & 10.7 & 0.1 \\
\hline & XP_424926 & Predicted similar to Dedicator of cytokinesis protein 8 & 5.3 & 9.0 & 1.6 \\
\hline & NP_990320 & fibrinogen, gamma chain & 5.3 & 9.4 & 1.2 \\
\hline & XP_424741 & Predicted similar to $\mathrm{BRCC} 3$ & 5.3 & 7.9 & 2.6 \\
\hline & XP_420282 & Predicted hypothetical protein & 5.2 & 10.1 & 0.3 \\
\hline & XP_ 419076 & Predicted similar to aryl hydrocarbon receptor repressor & 5.1 & 8.5 & 1.7 \\
\hline
\end{tabular}


(Table 1) contd...

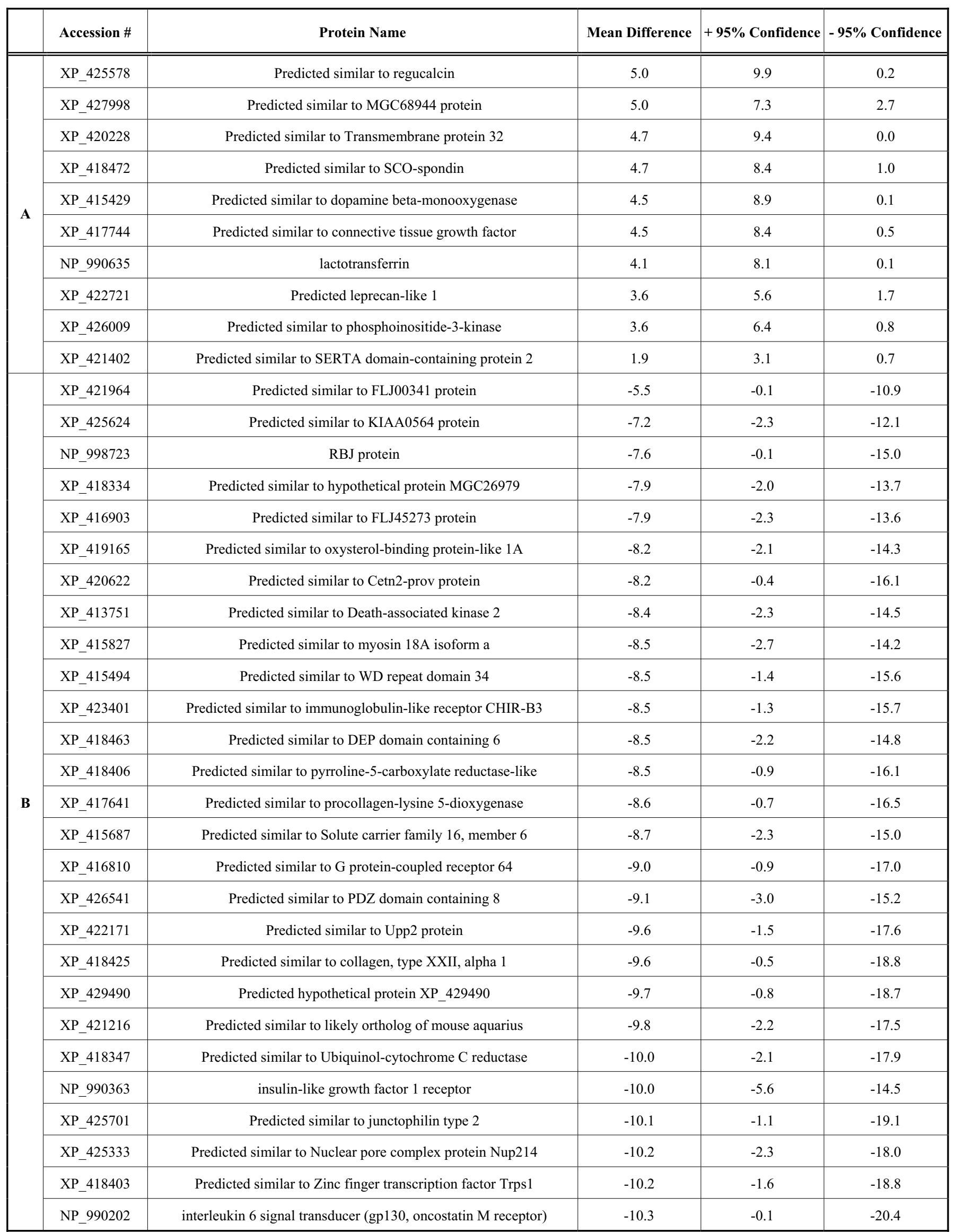


(Table 1) contd....

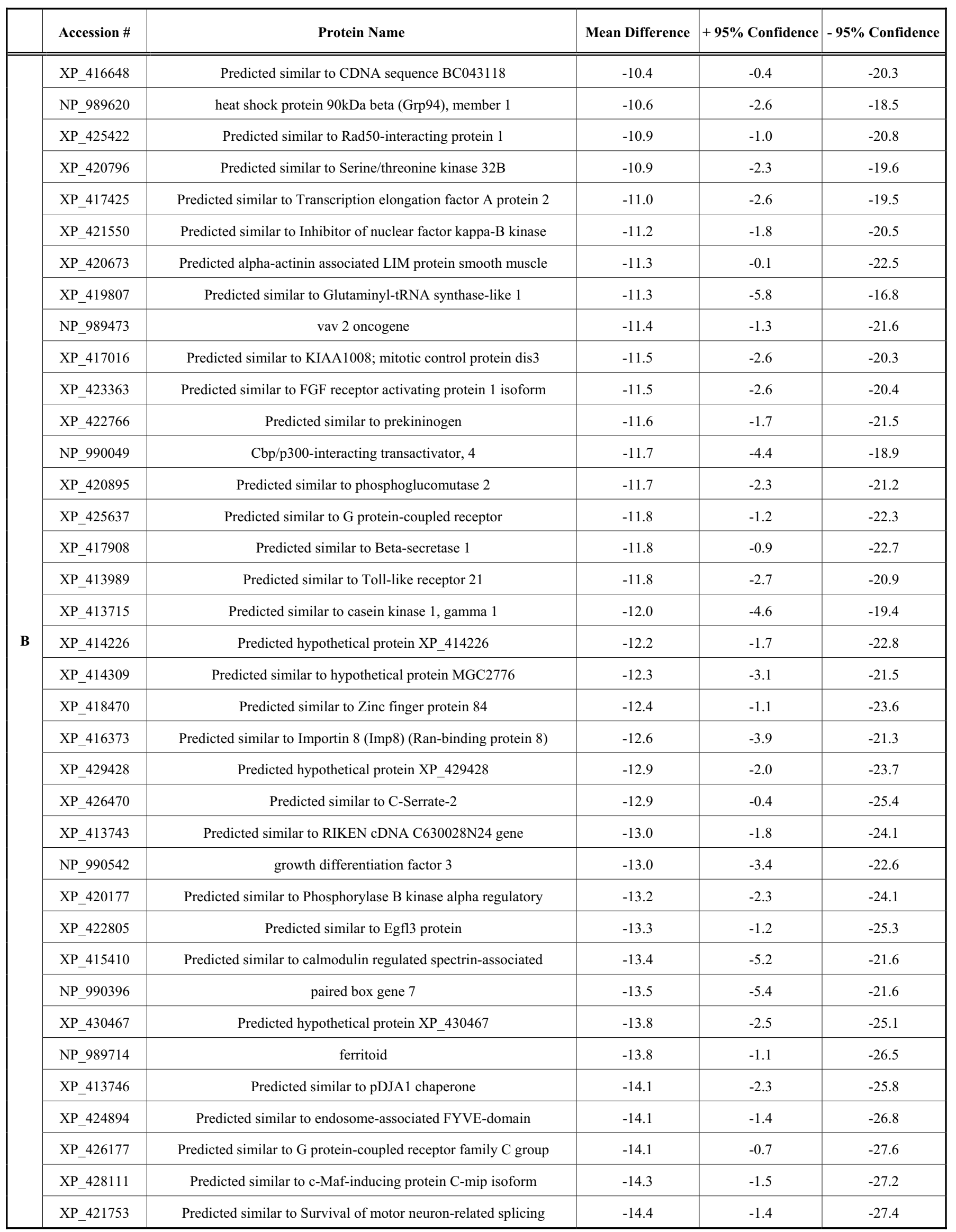


(Table 1) contd...

\begin{tabular}{|c|c|c|c|c|c|}
\hline & Accession \# & Protein Name & Mean Difference & $+95 \%$ Confidence & - 95\% Confidence \\
\hline \multirow{26}{*}{ B } & $\mathrm{XP} \_424678$ & Predicted similar to chromosome 10 open reading frame 88 & -14.4 & -1.6 & -27.2 \\
\hline & XP_429256 & Predicted hypothetical protein XP_429256 & -14.9 & -0.8 & -29.0 \\
\hline & $\mathrm{XP} 428859$ & Predicted similar to keratin associated protein $18-4$ & -15.0 & -2.4 & -27.5 \\
\hline & $\mathrm{XP} 425286$ & Predicted similar to 2210403 N09Rik protein & -15.0 & -2.0 & -28.1 \\
\hline & NP_996865 & vesicular acetylcholine transporter & -15.2 & 0.0 & -30.3 \\
\hline & XP_426521 & Predicted similar to KIAA0335 & -15.2 & -2.0 & -28.4 \\
\hline & XP_422735 & Predicted similar to proteasome $26 \mathrm{~S}$ non-ATPase subunit 1 & -15.2 & -1.5 & -28.9 \\
\hline & $\mathrm{XP} \_424160$ & Predicted hypothetical protein & -15.5 & -6.1 & -25.0 \\
\hline & $\mathrm{XP} \_422362$ & Predicted similar to collagen, type XXIV, alpha 1 & -15.6 & -3.0 & -28.2 \\
\hline & XP_426680 & Predicted similar to procollagen C-endopeptidase enhancer 2 & -16.0 & -2.2 & -29.8 \\
\hline & XP_422745 & Predicted similar to solute carrier family 12 , member 9 & -16.1 & -2.0 & -30.1 \\
\hline & XP_417685 & Predicted similar to Lysyl oxidase homolog 2 & -16.6 & -3.6 & -29.5 \\
\hline & $\mathrm{XP} \_422711$ & Predicted similar to optic atrophy 1 isoform 7 & -16.9 & -1.2 & -32.6 \\
\hline & $\mathrm{XP} 4414729$ & Predicted similar to RRN3 & -17.7 & -7.7 & -27.8 \\
\hline & XP_414389 & Predicted similar to Transcriptional adapter 3-like & -17.8 & -0.5 & -35.0 \\
\hline & $\mathrm{XP} \_423549$ & Predicted similar to ADAM 12 & -18.0 & -5.9 & -30.2 \\
\hline & XP_429787 & Predicted hypothetical protein XP_429787 & -19.0 & -1.5 & -36.6 \\
\hline & $\mathrm{XP}_{-} 421325$ & Predicted similar to putative NADH dehydrogenase 1 beta & -19.1 & -3.5 & -34.7 \\
\hline & XP_425727 & Predicted similar to Protein C20orf175 & -19.2 & -2.6 & -35.9 \\
\hline & XP_420346 & Predicted similar to hypertension-related calcium-regulated & -21.2 & -0.6 & -41.8 \\
\hline & $X P \_416764$ & Predicted similar to hypothetical protein FLJ22843 & -21.4 & -4.8 & -38.0 \\
\hline & $\mathrm{XP} 4417465$ & Predicted similar to Bactericidal permeability-increasing & -24.6 & -1.1 & -48.0 \\
\hline & $X P \_426269$ & Predicted similar to four and a half LIM domains 1 protein & -26.4 & -4.7 & -48.1 \\
\hline & XP_415685 & Predicted similar to regulator of G protein signaling RGS9-1 & -28.8 & -1.1 & -56.4 \\
\hline & XP_416618 & Predicted similar to hypothetical protein MGC15606 & -30.7 & -15.1 & -46.4 \\
\hline & XP_416042 & Predicted similar to $\mathrm{Mr} 93 \mathrm{~K}$ protein & -131.7 & -41.1 & -222.3 \\
\hline
\end{tabular}

expression values. Each accession number was mapped to its corresponding gene object in the Ingenuity Pathways Knowledge Base (IPKB). These genes were overlaid onto a global molecular network developed from information contained in the IPKB. Networks were then algorithmically generated based on their connectivity.

\section{RESULTS AND DISCUSSION}

\section{Protein Identification}

To compensate for ${ }^{18} \mathrm{O}$ labeling inefficiency, we labeled bidirectionally: triplicate tryptophan-adequate serum was labeled with ${ }^{16} \mathrm{O}$ while tryptophan-deficient serum was labeled with ${ }^{18} \mathrm{O}$ and vice versa. We identified 4161 proteins represented by peptides labeled in both directions (i.e. by definition all were identified by at least two peptides). Fur- ther analysis was limited to these proteins only. Relative to the tryptophan-sufficient group, 46 proteins had increased and 90 decreased expression in the serum from tryptophan deficient chickens (Table 1). This represents $\sim 3 \%$ of the proteins analyzed.

\section{GO Annotation}

We were able to GO-annotate $50 \%$ of the differentially expressed proteins. Application of the generic GO slim to the data resulted in 14 functional categories (Fig. 2). The majority of these categories, including processes such as transport and cell communication, showed overall down-regulation. Amino acid and derivative metabolism was the only category with overall up-regulation. Although GO slims are used to group the very detailed GO biological process annotations 


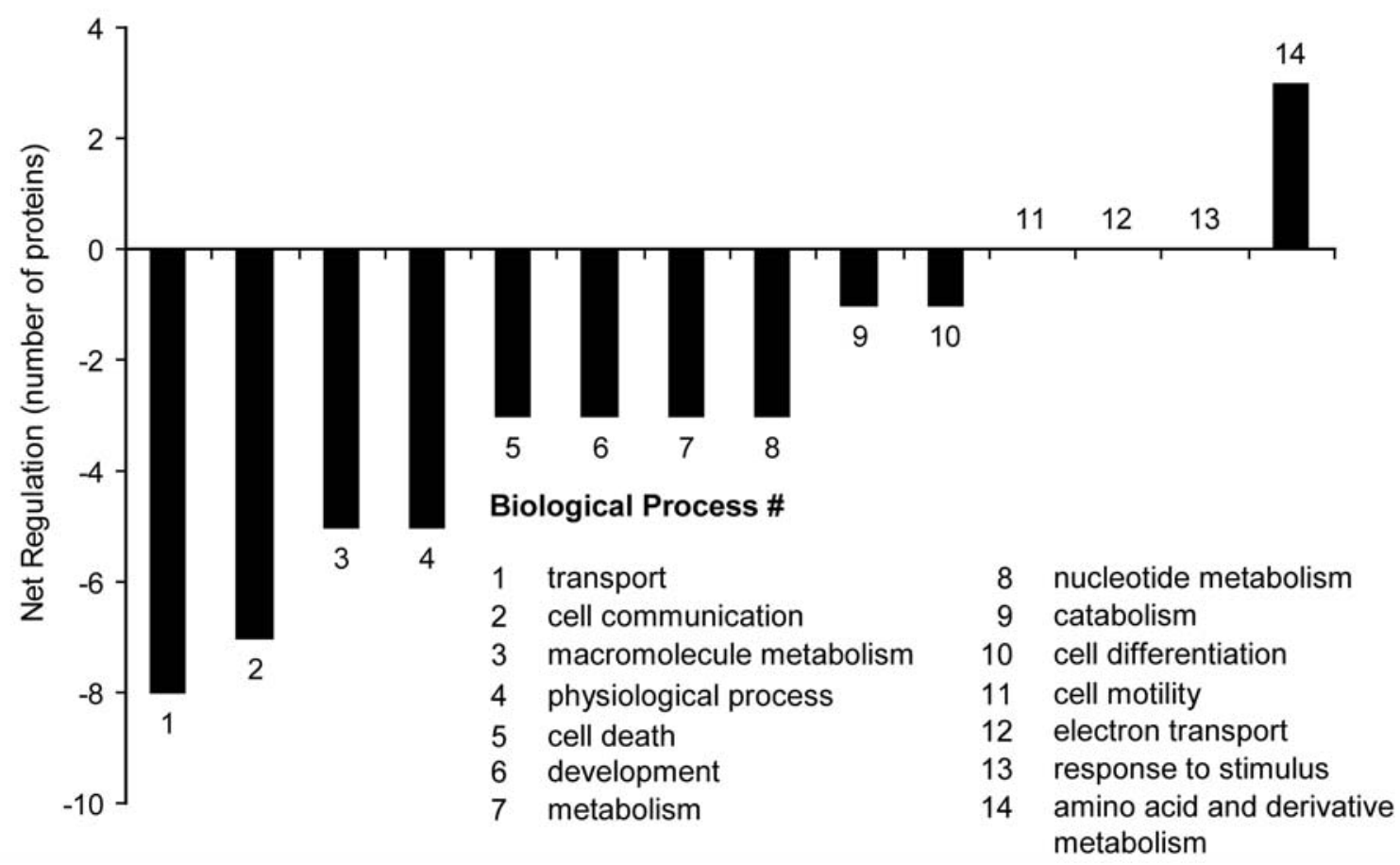

Fig. (2). All increased and decreased proteins were GO-annotated by biological process and then grouped into more general categories using a generic GO slim [21] available via GOSlimViewer at AgBase (www.agbase.msstate.edu) [20, 22] The number of proteins decreased in a given GO slim category was subtracted from the number of proteins that had increased to determine the net regulatory effect. Notably, the only category in which protein expression has increased overall is amino acid and derivative metabolism; possibly as a compensatory mechanism.

into more general categories, these generalized categories often provide only limited information. For instance, overall down-regulation of transport does not provide specific information about how the transport proteins interact with other molecules or their roles in specific physiological processes and diseases.

\section{IPA Modeling}

We next modeled our differentially expressed proteins using IPA. IPA allows us to identify whether the differentially expressed proteins cluster into common pathways. Our differentially expressed proteins mapped to 4 networks (Fig. 3). These four major networks (designated A-D; Fig. 3A-D) had $34-37 \%$ coverage in our dataset of differentially regulated proteins. Coverage of these networks in our entire dataset of identified proteins, although probably much greater, was not determined because our focus was on biomarkers. These networks include expected physiological processes such as autoimmunity and neurological disorders but they also described cancer, optic atrophy and cardiomyopathy. Each of these four networks is focused around 1-3 central hub proteins that reflect the general functions affected within each network and we will discuss each in detail.

\section{The Four Major Networks}

NETWORK $A$ (Fig. 3A) is centered on transforming growth factor beta 1 (TGFB1). TGFB1 is involved in inflammation and numerous autoimmune disorders as well as tumorigenesis and metastasis of many types of cancer [23, 24]. The link between inflammation and cancer is well known [25] and so this is perhaps not surprising. This first network pathway model suggests tryptophan deficiency is involved in autoimmune, dermatological, connective tissue disorders and cancer. We found increased expression of connective tissue growth factor (CTGF). Increased CTGF expression is associated with increased inflammation in rheumatoid arthritis and in response to allografts [26, 27]. We also found markers of Ehlers-Danlos Syndromes (EDSs) I, II and VI (decreased PLOD1 and decreased COL5A1) [28, 29]. EDSs, caused by mutations in the PLOD1 and COL5A1 genes, are characterized by loose-jointedness, easily bruised or stretchable skin and scoliosis [30]. The immune system and cancer formation are linked through the immune response to cancer and here we found evidence of a specific mechanism of potential cancer immune escape. HSP90B1, a tumor rejection protein that elicits immune response by activation of dendritic cells and cytotoxic T-cells [31], is decreased. This network also suggests a direct role for tryptophan deficiency in cancer. Specifically, SDC2, which promotes activity, growth, proliferation, morphology and adhesion of colon cancer cell lines [32] was increased. In contrast, however, PSMD1 and TRPS1 were decreased. Increased PSMD1 and TRPS1 is associated with breast cancer $[33,34]$ and decreased TRPS1 also prevents apoptosis of prostate cancer cells [35], decreased PSMD1 and TRPS1 in our dataset may represent compensatory mechanisms for the increase in SDC2.

In contrast to NETWORK A, NETWORK B (Fig. 3B) has three major hubs: Tata box-binding protein (TBP), tumor suppressor protein $\mathrm{p} 53$ (TP53) and Sp1 transcription factor (SP1) (Fig. 3B). TBP is a transcription factor associated with 

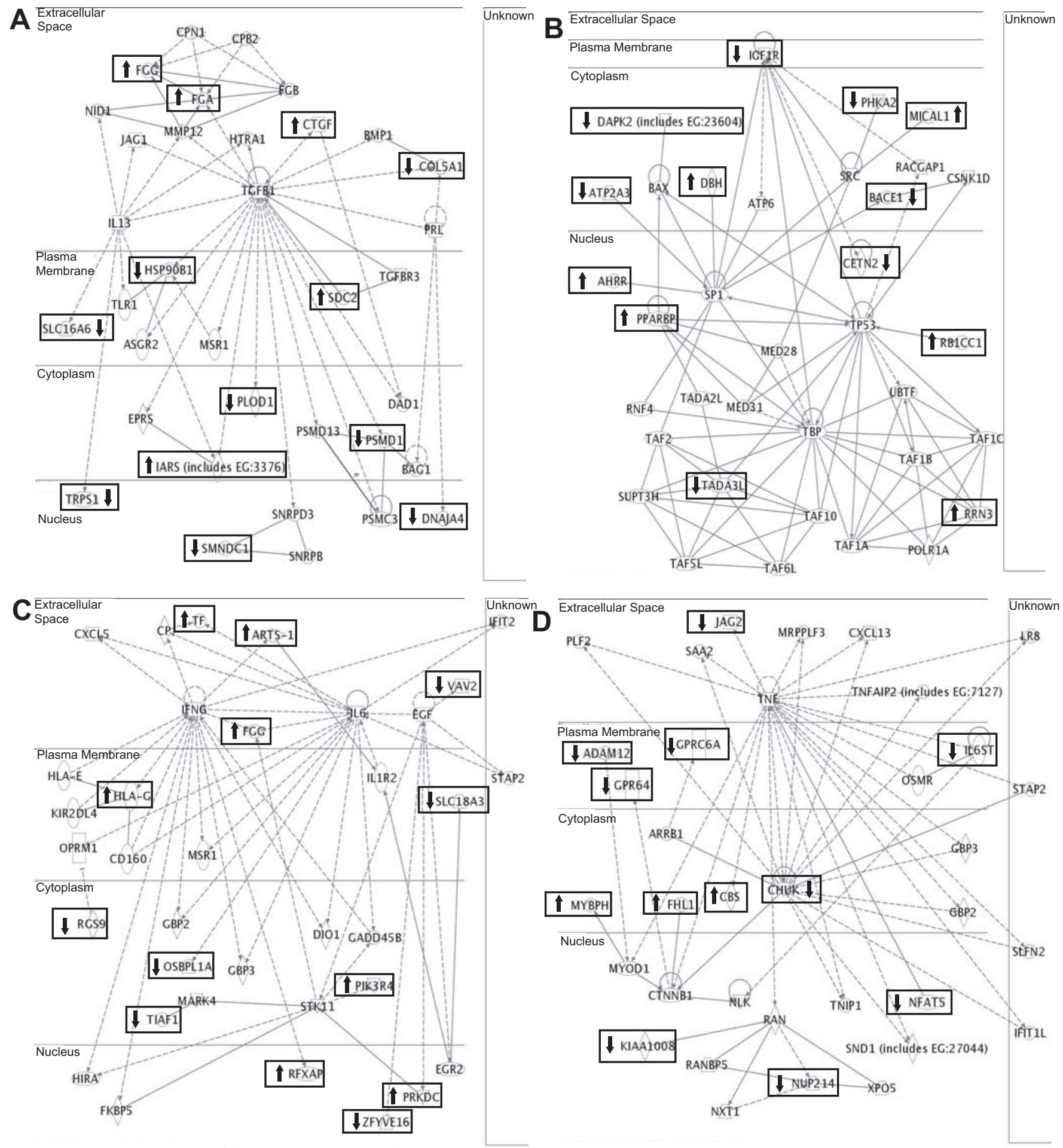

Fig. (3). The four major networks of differentially expressed proteins. Increased and decreased proteins were mapped using IPA software as described in M \& M. The top four resulting networks are shown here relative to protein cellular localization. Nodes are displayed using various shapes that represent the functional class of the gene product. Nodes representing identified proteins are framed. Arrows indicate increase or decrease in our dataset. 
the neurological disorders spinocerebellar ataxia 17 and Huntington's disease. P53, located in the cell nucleus, is one of the major cell cycle checkpoint regulators in cancer biology [36]; decreased P53 promotes apoptosis and cell cycle arrest [37]. P53 is also involved in non-neoplastic diseases such as amyotrophic lateral sclerosis (ALS, Lou Gehrig's disease) and Huntington's disease. SP1 promotes apoptosis, cell cycle regulation and again is involved in Huntington's disease cell signaling.

The other proteins that we identified within Network B again support a role for tryptophan in cancer. Decreased expression of three of these proteins suggests a pro-cancer state: Sarcoplasmic-endoplasmic reticulum calcium ATPase 3 (ATP2A3), which controls intracellular calcium homeostasis and decreases in colon cancer [38]; transcription factor TADA3L, necessary for P53-mediated apoptosis [39]; and IGF1R, which is over-expressed in malignant tissues and is anti-apoptotic [40]. In contrast, death-associated protein kinase 2 (DAPK2) was decreased and the anti-apoptotic protein PPARBP was increased. Centrin-2 (CETN2), required for centriole duplication during cell division [41], was decreased; improper centriole duplication correlates with aggressive tumors [42]. Retinoblastoma 1 coiled-coil 1 (RB1$\mathrm{CC} 1$ ) was increased and $\mathrm{RB} 1 \mathrm{CC} 1$ positively regulates the tumor suppressor protein retinoblastoma 1 and is frequently over-expressed in breast cancer [43]. Together DAPK2, CETN2 and RB1CC1 may be signs of cellular responses to pro-neoplastic signals.

In addition to cancer, we identified differential expression of several proteins, outside of the hubs, involved in Alzheimer's disease. Dopamine beta-hydroxylase (DBH), responsible for conversion of dopamine to norepinephrine, was increased and supports previous work showing that excess dietary tryptophan decreases norepinephrine in blood plasma [44]. DBH also blocks selective serotonin reuptake inhibitors (SSRI) thus decreasing the concentration of serotonin, a tryptophan derivative, in the hippocampus [45]. PPARBP was also increased. Increased hippocampal concentrations of both DBH and PPARBP mRNA in peripheral blood leukocytes have been associated with Alzheimer's disease symptoms [46, 47]. Beta-secretase 1 and casein kinase 1 gamma were decreased in tryptophan deficiency. Betasecretase 1 is an enzyme responsible for the proteolytic processing of the amyloid precursor protein [38] into betaamyloid peptides, which form the fibrillar plaques characteristic of Alzheimer's disease [48]. Although little is known about the function of casein kinase-1 (CK-1)- $\gamma$, it belongs to the same family as CK-1- $\delta$ and over-expression of CK-1- $\delta$ promotes hyperphosphorylation of tau in Alzheimer's disease pathology [49].

Tryptophan plays a role in the regulation of toxicity responses and circadian rhythms [50]. Aryl hydrocarbon receptor repressor (AhRR), a nuclear protein that represses aryl hydrocarbon receptor (AhR) activity through competitive binding, was increased. AhR mediates the effects of environmental toxicants such as dioxin by inducing transcription of proteins involved in apoptosis and cell cycle regulation [51], it induces transcription of genes including cytochrome p450, family 1, subfamily A, polypeptide 1 (CYP1A1) [52]. However, AhR responds not only to xenobiotic compounds, but also to endogenous aromatic molecules including the photoproducts of tryptophan [53]. AhR may also regulate light-dependent circadian rhythms through the binding of tryptophan photoproducts [50]. Our data further implicate tryptophan in the regulation of the sleep wake cycle, a process in which it plays a key role as the precursor of melatonin.

While we were modeling the affects of AhRR using IPA, we found an error: AhRR is annotated in the IPKB as a synonym of CYP1A1; but CYP1A1 is not annotated in IPKB as a synonym of AhRR. These proteins not synonymous: AhRR carries the human genome nomenclature committee identi-

fication number (HGNCID\#) 346, whereas CYP1A1 carries HGNCID\# 25 [54]. AhRR in conjunction with AhR regulate the expression of CYP1A1 [55]. Further, when AhRR and CYP1A1 are mapped interchangeably using IPA, each as a part of the same dataset, they map to different networks and this further reflects their differences.

NETWORK C (Fig. 3C) is centered on interleukin 6 (IL6) and interferon (IFN) $\gamma$ (Fig. 3C). IL-6 and INF $\gamma$ are cytokines involved in immunity and cancer. Again, the other proteins in NETWORK $\mathrm{C}$ affect cancer, autoimmunity and neurotransmission and provide a link with NETWORK A. Favoring cancer, TGFB1-induced anti-apoptotic factor 1 (TIAF1) was decreased and phosphoinositide-3-kinase regulatory subunit 4 (PIK3R4), which is anti-apoptotic and overexpressed during early tumor development [56], was increased.

NETWORK $C$ also suggests increased antigen presentation and autoimmunity: major histocompatibility antigen class (MHC) I, the molecule responsible for antigen presentation to CD8+ T-killer cells, was increased along with Adipocyte-derived leucine aminopeptidase precursor (ARTS1) and regulatory factor X-associated protein (RFXAP). ARTS1 promotes endogenous antigen presentation via MHC I [57]. RFXAP is a transcription factor that increases $\mathrm{MCH}$ II [58] expression (MHC II presents antigens to CD4+ Thelper cells and T-regulatory cells). ARTS1 also increases shedding of the IL-6 receptor (IL-6R) [57] and increased concentrations of soluble IL-6R are associated with chronic inflammatory and autoimmune disorders including rheumatoid arthritis, asthma and colitis [59]. In addition, we found decreased VAV2 expression, which is responsible for decreased killing of cytotoxic $T$ cells, resulting in increased immune response [60] and this could promote autoimmunity. The protein called "protein kinase, DNA-activated, catalytic polypeptide" (PRKDC) was decreased and this is also consistent with increased immune responsiveness [61].

Again, we identified a link with NETWORKS A and B via monoamine transporters. Vesicular acetylcholine transporter solute carrier family 18, member 3 (SLC18A3) belongs to the vesicular amine transporter family that also includes the monoamine transporters SLC18A1 and SLC18A2. SLC18A3 was decreased and this decrease could reflect its involvement in monoamine transport as it would in the mouse [62]. However, acetylcholine transport may also be affected by tryptophan deficiency as a part of the neurological disruptions identified in network B and increased expression of SLC18A3 is associated with Alzheimer's disease [63].

NETWORK D (Fig. 3D), like NETWORK C, has two major hub proteins: tumor necrosis factor (TNF) and conserved 
helix-loop-helix ubiquitous kinase (CHUK). TNF is a cytokine involved in multiple signaling pathways related to apoptosis and immune response. CHUK is a member of the NFkB signaling pathway. CHUK was decreased in our data set and decreases in CHUK cause apoptosis and reduced immune response through the NFkB signaling pathway [64]. This is inconsistent with most of our modeling. However, CHUK can also act independently of NFkB and in this case CHUK decreases cause hyperproliferation and incomplete differentiation [65], both consistent with inflammation and cancer. Down-regulation of nucleoporin $214 \mathrm{kDa}$ (NUP214), identified here, causes impaired cell cycle regulation and is associated with acute myeloid leukemia [66].

Within NETWORK D we found differential expression of other proteins responsible for increased $\mathrm{T}$ cell immune response and inflammation. Disintegrin and metalloprotease domain 12 (ADAM12) were decreased, potentially increasing inflammation [67]. Jagged 2, IL-6ST and nuclear factor of activated T cells 5 (NFAT5) were also decreased and suggest decreased negative selection and cell death of thymocytes again potentially increasing autoimmunity $[68,69]$. Lower NFAT5 and IL-6ST levels favor the production of $\mathrm{CD} 4+$ and $\mathrm{CD} 8+\mathrm{T}$ cells (the latter through the activation of Notch1) [70, 71]. Decreased IL-6ST also causes increased growth and infiltration of $\mathrm{T}$ cells and accumulation of memory $\mathrm{T}$ cells $[68,72]$ and increases chronic inflammation of the synovial joint, metaplasia of cartilage tissues and autoimmune arthritis [73, 74]. Consequently, soluble IL-6ST is suggested for treating rheumatoid arthritis, asthma, Crohn's disease and inflammatory colon cancer [75]. Again, several proteins in network $\mathrm{D}$ can affect non-immune/cancer disorders. IL6-ST acts as the signal transducer not only for IL-6 but also for other proteins. Through its binding of oncostatin M, IL-6ST plays a role in cardiac remodeling and repair and decreased IL-6ST is a marker of dilated cardiomyopathy [76, 77]. We also found decreased FHL1 and increased ADAM12 ; over-expression of both is associated with cardiomyopathy $[78,79]$.

\section{CONCLUSION}

We have used bi-directional ${ }^{16 / 18} \mathrm{O}$ labeling, and the plant protein $\mathrm{RuBisCO}$ as an internal standard, to do serum proteomics on a chicken model of tryptophan deficiency. This method allowed us to maximize our pool of potential biomarkers. Overall, we found that dietary tryptophan status is involved in not only the expected physiological processes such as immune tolerance, circadian rhythm and neurological function, but may also be associated with apoptosis, cell cycle regulation and toxicity response as well as dermatological, ophthalmic and cardiovascular diseases.

\section{ACKNOWLEDGEMENTS}

This research was supported by grants from the Life Sciences and Biotechnology Institute, MSU. The authors thank T. Pechan for technical help running the mass spectrometer. This paper is Mississippi Agricultural and Forestry Experiment Station publication number J-11137.

\section{REFERENCES}

[2] Suarez, E.C.; Krishnan, K.R. Ann. Behav. Med., 2006, 31(3), 25460.

[3] Levitan, R.D.; Shen, J.H.; Jindal, R.; Driver, H.S.; Kennedy, S.H.; Shapiro, C.M. J. Psychiatry Neurosci., 2000, 25(4), 337-46.

[4] Schernhammer, E.S.; Rosner, B.; Willett, W.C.; Laden, F.; Colditz, G.A.; Hankinson, S.E. Cancer Epidemiol. Biomarkers Prev., 2004, 13(6), 936-43.

[5] Spinweber, C.L. Psychopharmacology (Berl), 1986, 90(2), 151-5.

[6] Wilson, T.C.; Levy, G. J. Pharm. Sci., 1994, 83(10), 1433-6.

[7] Mellor, A.L.; Munn, D.H. Nat. Rev. Immunol., 2004, 4(10), 762-74.

[8] Fallarino, F.; Grohmann, U.; Hwang, K.W.; Orabona, C.; Vacca, C.; Bianchi, R.; Belladonna, M.L.; Fioretti, M.C.; Alegre, M.L.; Puccetti, P. Nat. Immunol., 2003, 4(12), 1206-12.

[9] Munn, D.H.; Sharma, M.D.; Hou, D.; Baban, B.; Lee, J.R.; Antonia, S.J.; Messina, J.L.; Chandler, P.; Koni, P.A.; Mellor, A.L. J. Clin. Invest., 2004, 114(2), 280-90.

[10] Sakurai, K.; Zou, J.P.; Tschetter, J.R.; Ward, J.M.; Shearer, G.M. J. Neuroimmunol., 2002, 129(1-2), 186-96.

[11] Gurtner, G.J.; Newberry, R.D.; Schloemann, S.R.; McDonald, K.G.; Stenson, W.F. Gastroenterology, 2003, 125(6), 1762-73.

[12] Hayashi, T.; Beck, L.; Rossetto, C.; Gong, X.; Takikawa, O.; Takabayashi, K.; Broide, D.H.; Carson, D.A.; Raz, E. J. Clin. Invest., 2004, 114(2), 270-9.

[13] Stewart, II; Thomson, T.; Figeys, D. Rapid. Commun. Mass Spectrom., 2001, 15(24), 2456-65.

[14] Hillier, L.W.; Miller, W.; Birney, E.; Warren, W.; Hardison, R.C.; Ponting, C.P.; Bork, P.; Burt, D.W.; Groenen, M.A.; Delany, M.E.; Dodgson, J.B.; Chinwalla, A.T.; Cliften, P.F.; Clifton, S.W.; Delehaunty, K.D.; Fronick, C.; Fulton, R.S.; Graves, T.A.; Kremitzki, C.; Layman, D.; Magrini, V.; McPherson, J.D.; Miner, T.L.; Minx, P.; Nash, W.E.; Nhan, M.N.; Nelson, J.O.; Oddy, L.G.; Pohl, C.S.; Randall-Maher, J.; Smith, S.M.; Wallis, J.W.; Yang, S.P.; Romanov, M.N.; Rondelli, C.M.; Paton, B.; Smith, J.; Morrice, D.; Daniels, L.; Tempest, H.G.; Robertson, L.; Masabanda, J.S.; Griffin, D.K.; Vignal, A.; Fillon, V.; Jacobbson, L.; Kerje, S.; Andersson, L.; Crooijmans, R.P.; Aerts, J.; van der Poel, J.J.; Ellegren, H.; Caldwell, R.B.; Hubbard, S.J.; Grafham, D.V.; Kierzek, A.M.; McLaren, S.R.; Overton, I.M.; Arakawa, H.; Beattie, K.J.; Bezzubov, Y.; Boardman, P.E.; Bonfield, J.K.; Croning, M.D.; Davies, R.M.; Francis, M.D.; Humphray, S.J.; Scott, C.E.; Taylor, R.G.; Tickle, C.; Brown, W.R.; Rogers, J.; Buerstedde, J.M.; Wilson, S.A.; Stubbs, L.; Ovcharenko, I.; Gordon, L.; Lucas, S.; Miller, M.M.; Inoko, H.; Shiina, T.; Kaufman, J.; Salomonsen, J.; Skjoedt, K.; Wong, G.K.; Wang, J.; Liu, B.; Wang, J.; Yu, J.; Yang, H.; Nefedov, M.; Koriabine, M.; Dejong, P.J.; Goodstadt, L.; Webber, C.; Dickens, N.J.; Letunic, I.; Suyama, M.; Torrents, D.; von Mering, C.; Zdobnov, E.M.; Makova, K.; Nekrutenko, A.; Elnitski, L.; Eswara, P.; King, D.C.; Yang, S.; Tyekucheva, S.; Radakrishnan, A.; Harris, R.S.; Chiaromonte, F.; Taylor, J.; He, J.; Rijnkels, M.; Griffiths-Jones, S.; Ureta-Vidal, A.; Hoffman, M.M.; Severin, J.; Searle, S.M.; Law, A.S.; Speed, D.; Waddington, D.; Cheng, Z.; Tuzun, E.; Eichler, E.; Bao, Z.; Flicek, P.; Shteynberg, D.D.; Brent, M.R.; Bye, J.M.; Huckle, E.J.; Chatterji, S.; Dewey, C.; Pachter, L.; Kouranov, A.; Mourelatos, Z.; Hatzigeorgiou, A.G.; Paterson, A.H.; Ivarie, R.; Brandstrom, M.; Axelsson, E.; Backstrom, N.; Berlin, S.; Webster, M.T.; Pourquie, O.; Reymond, A.; Ucla, C.; Antonarakis, S.E.; Long, M.; Emerson, J.J.; Betran, E.; Dupanloup, I.; Kaessmann, H.; Hinrichs, A.S.; Bejerano, G.; Furey, T.S.; Harte, R.A.; Raney, B.; Siepel, A.; Kent, W.J.; Haussler, D.; Eyras, E.; Castelo, R.; Abril, J.F.; Castellano, S.; Camara, F.; Parra, G.; Guigo, R.; Bourque, G.; Tesler, G.; Pevzner, P.A.; Smit, A.; Fulton, L.A.; Mardis, E.R.; Wilson, R.K. Nature, 2004, 432(7018), 695-716.

Aviagen North America, Broiler Management Guide, 2005. Llames, C.; Fontaine, J. J. AOAC Int., 1994, 77, 1362-402.

Strausberg, R.L.; Feingold, E.A.; Grouse, L.H.; Derge, J.G.; Klausner, R.D.; Collins, F.S.; Wagner, L.; Shenmen, C.M.; Schuler, G.D.; Altschul, S.F.; Zeeberg, B.; Buetow, K.H.; Schaefer, C.F.; Bhat, N.K.; Hopkins, R.F.; Jordan, H.; Moore, T.; Max, S.I.; Wang, J.; Hsieh, F.; Diatchenko, L.; Marusina, K.; Farmer, A.A.; Rubin, G.M.; Hong, L.; Stapleton, M.; Soares, M.B.; Bonaldo, M.F.; Casavant, T.L.; Scheetz, T.E.; Brownstein, M.J.; Usdin, T.B.; Toshiyuki, S.; Carninci, P.; Prange, C.; Raha, S.S.; Loquellano, N.A.; Peters, G.J.; Abramson, R.D.; Mullahy, S.J.; Bosak, S.A.; McEwan, P.J.; McKernan, K.J.; Malek, J.A.; Gunaratne, P.H.; Richards, 
S.; Worley, K.C.; Hale, S.; Garcia, A.M.; Gay, L.J.; Hulyk, S.W.; Villalon, D.K.; Muzny, D.M.; Sodergren, E.J.; Lu, X.; Gibbs, R.A.; Fahey, J.; Helton, E.; Ketteman, M.; Madan, A.; Rodrigues, S.; Sanchez, A.; Whiting, M.; Madan, A.; Young, A.C.; Shevchenko, Y.; Bouffard, G.G.; Blakesley, R.W.; Touchman, J.W.; Green, E.D.; Dickson, M.C.; Rodriguez, A.C.; Grimwood, J.; Schmutz, J.; Myers, R.M.; Butterfield, Y.S.; Krzywinski, M.I.; Skalska, U.; Smailus, D.E.; Schnerch, A.; Schein, J.E.; Jones, S.J.; Marra, M.A. Proc. Natl. Acad. Sci. USA, 2002, 99(26), 16899-903.

[18] Link, A.J.; Eng, J.; Schieltz, D.M.; Carmack, E.; Mize, G.J.; Morris, D.R.; Garvik, B.M.; Yates, J.R. 3rd. Nat. Biotechnol., 1999, 17(7), 676-82

[19] Nanduri, B.; Lawrence, M.L.; Vanguri, S.; Burgess, S.C. Proteomics, 2005, 5(18), 4852-63.

[20] McCarthy, F.M.; Bridges, S.M.; Wang, N.; Magee, G.B.; Williams, W.P.; Luthe, D.S.; Burgess, S.C. Nucleic Acids Res., 2007, 35, D599-603.

[21] Dunning, A.M.; Ellis, P.D.; McBride, S.; Kirschenlohr, H.L.; Healey, C.S.; Kemp, P.R.; Luben, R.N.; Chang-Claude, J.; Mannermaa, A.; Kataja, V.; Pharoah, P.D.; Easton, D.F.; Ponder, B.A.; Metcalfe, J.C. Cancer Res., 2003, 63(10), 2610-5.

[22] Sancho, D.; Gomez, M.; Viedma, F.; Esplugues, E.; GordonAlonso, M.; Garcia-Lopez, M.A.; de la Fuente, H.; Martinez, A.C.; Lauzurica, P.; Sanchez-Madrid, F. J. Clin. Invest., 2003, 112(6), $872-82$.

[23] Coussens, L.M.; Werb, Z. Nature, 2002, 420(6917), 860-7.

[24] Cheng, O.; Thuillier, R.; Sampson, E.; Schultz, G.; Ruiz, P.; Zhang, X.; Yuen, P.S.; Mannon, R.B. Am. J. Transplant., 2006, 6(10), 2292-306.

[25] Hattori, T.; Kawaki, H.; Kubota, S.; Yutani, Y.; de Crombrugghe, B.; von der Mark, K.; Takigawa, M. J. Cell Physiol., 2003, 197(1), 94-102.

[26] Nicholls, A.C.; Oliver, J.E.; McCarron, S.; Harrison, J.B.; Greenspan, D.S.; Pope, F.M. J. Med. Genet., 1996, 33(11), 940-6.

[27] Pinnell, S.R.; Krane, S.M.; Kenzora, J.E.; Glimcher, M.J. N. Engl. J. Med., 1972, 286(19), 1013-20.

[28] Beighton, P.; De Paepe, A.; Steinmann, B.; Tsipouras, P.; Wenstrup, R.J. Am. J. Med. Genet., 1998, 77(1), 31-7.

[29] Hilf, N.; Singh-Jasuja, H.; Schwarzmaier, P.; Gouttefangeas, C.; Rammensee, H.G.; Schild, H. Blood, 2002, 99(10), 3676-82.

[30] Park, H.; Kim, Y.; Lim, Y.; Han, I.; Oh, E.S. J. Biol. Chem., 2002, 277(33), 29730-6.

[31] Deng, S.; Zhou, H.; Xiong, R.; Lu, Y.; Yan, D.; Xing, T.; Dong, L.; Tang, E.; Yang, H. Breast Cancer Res. Treat., 2007, 104(1), 21-30.

[32] Radvanyi, L.; Singh-Sandhu, D.; Gallichan, S.; Lovitt, C.; Pedyczak, A.; Mallo, G.; Gish, K.; Kwok, K.; Hanna, W.; Zubovits, J.; Armes, J.; Venter, D.; Hakimi, J.; Shortreed, J.; Donovan, M.; Parrington, M.; Dunn, P.; Oomen, R.; Tartaglia, J.; Berinstein, N.L. Proc. Natl. Acad. Sci. USA, 2005, 102(31), 11005-10.

[33] Chang, G.T.; van den Bemd, G.J.; Jhamai, M.; Brinkmann, A.O. Apoptosis, 2002, 7(1), 13-21.

[34] Levine, A.J.; Momand, J.; Finlay, C.A. Nature, 1991, 351(6326), 453-6.

[35] Yonish-Rouach, E.; Grunwald, D.; Wilder, S.; Kimchi, A.; May, E.; Lawrence, J.J.; May, P.; Oren, M. Mol. Cell Biol., 1993, 13(3), 1415-23.

[36] Brouland, J.P.; Gelebart, P.; Kovacs, T.; Enouf, J.; Grossmann, J.; Papp, B. Am. J. Pathol., 2005, 167(1), 233-42.

[37] Wang, T.; Kobayashi, T.; Takimoto, R.; Denes, A.E.; Snyder, E.L.; el-Deiry, W.S.; Brachmann, R.K. EMBO J., 2001, 20(22), 6404-13.

[38] Yeh, A.H.; Bohula, E.A.; Macaulay, V.M. Oncogene, 2006, 25(50), 6574-81

[39] Salisbury, J.L.; Suino, K.M.; Busby, R.; Springett, M. Curr. Biol., 2002, 12(15), 1287-92.

[40] D'Assoro, A.B.; Stivala, F.; Barrett, S.; Ferrigno, G.; Salisbury, J.L. Ital. J. Anat. Embryol., 2001, 106(2 Suppl 1), 103-10.

[41] Chano, T.; Kontani, K.; Teramoto, K.; Okabe, H.; Ikegawa, S. Nat. Genet., 2002, 31(3), 285-8.

[42] Koopmans, S.J.; Ruis, M.; Dekker, R.; van Diepen, H.; Korte, M.; Mroz, Z. Physiol. Behav., 2005, 85(4), 469-78.

[43] Cryan, J.F.; O'Leary, O.F.; Jin, S.H.; Friedland, J.C.; Ouyang, M.; Hirsch, B.R.; Page, M.E.; Dalvi, A.; Thomas, S.A.; Lucki, I. Proc. Natl. Acad. Sci. USA, 2004, 101(21), 8186-91.
[44] Blalock, E.M.; Geddes, J.W.; Chen, K.C.; Porter, N.M.; Markesbery, W.R.; Landfield, P.W. Proc. Natl. Acad. Sci. USA, 2004, 101(7), 2173-8.

[45] Giubilei, F.; Calderaro, C.; Antonini, G.; Sepe-Monti, M.; Tisei, P.; Brunetti, E.; Marchione, F.; Caronti, B.; Pontieri, F.E. Dement Geriatr. Cogn. Disord., 2004, 18(3-4), 338-41.

[46] Cai, H.; Wang, Y.; McCarthy, D.; Wen, H.; Borchelt, D.R.; Price, D.L.; Wong, P.C. Nat. Neurosci., 2001, 4(3), 233-4.

[47] Singh, T.J.; Grundke-Iqbal, I.; Iqbal, K. J. Neurochem., 1995, 64(3), 1420-3.

[48] Mukai, M.; Tischkau, S.A. Toxicol. Sci., 2007, 95(1), 172-81.

[49] Nebert, D.W.; Roe, A.L.; Dieter, M.Z.; Solis, W.A.; Yang, Y.; Dalton, T.P. Biochem. Pharmacol., 2000, 59(1), 65-85.

[50] Quattrochi, L.C.; Tukey, R.H. Mol. Pharmacol., 1993, 43(4), 5048 .

[51] Diani-Moore, S.; Labitzke, E.; Brown, R.; Garvin, A.; Wong, L.; Rifkind, A.B. Toxicol. Sci., 2006, 90(1), 96-110.

[52] HUGO Gene Nomenclature Committee. HGNC gene symbol. http://www.gene.ucl.ac.uk/nomenclature/index.html (accessed Aug. 12 , 2006).

[53] Watanabe, T.; Imoto, I.; Kosugi, Y.; Fukuda, Y.; Mimura, J.; Fujii, Y.; Isaka, K.; Takayama, M.; Sato, A.; Inazawa, J. J. Hum. Genet, 2001, 46(6), 342-6.

[54] Cerezo-Guisado, M.I.; Garcia-Marin, L.J.; Lorenzo, M.J.; Bragado, M.J. J. Neurochem., 2005, 94(5), 1277-87.

[55] Cui, X.; Rouhani, F.N.; Hawari, F.; Levine, S.J. J. Biol. Chem., 2003, 278(31), 28677-85.

[56] Durand, B.; Sperisen, P.; Emery, P.; Barras, E.; Zufferey, M.; Mach, B.; Reith, W. EMBO J., 1997, 16(5), 1045-55.

[57] Scheller, J.; Ohnesorge, N.; Rose-John, S. Scand. J. Immunol, 2006, 63(5), 321-9.

[58] Billadeau, D.D.; Mackie, S.M.; Schoon, R.A.; Leibson, P.J. J. Exp Med., 2000, 192(3), 381-92.

[59] Araki, R.; Fujimori, A.; Hamatani, K.; Mita, K.; Saito, T.; Mori, M.; Fukumura, R.; Morimyo, M.; Muto, M.; Itoh, M.; Tatsumi, K.; Abe, M. Proc. Natl. Acad. Sci. USA, 1997, 94(6), 2438-43.

[60] Naciff, J.M.; Misawa, H.; Dedman, J.R. Neuroreport, 1997, 8(16), 3467-73.

[61] Heinitz, K.; Beck, M.; Schliebs, R.; Perez-Polo, J.R. J. Neurochem., 2006, 98(6), 1930-45.

[62] Ghosh, S.; May, M.J.; Kopp, E.B. Annu. Rev. Immunol., 1998, 16 , 225-60.

[63] Hu, Y.; Baud, V.; Oga, T.; Kim, K.I.; Yoshida, K.; Karin, M. Nature, 2001, 410(6829), 710-4.

[64] van Deursen, J.; Boer, J.; Kasper, L.; Grosveld, G. EMBO J., 1996 15(20), 5574-83.

[65] Kronqvist, P.; Kawaguchi, N.; Albrechtsen, R.; Xu, X.; Schroder, H.D.; Moghadaszadeh, B.; Nielsen, F.C.; Frohlich, C.; Engvall, E.; Wewer, U.M. Am. J. Pathol., 2002, 161(5), 1535-40.

[66] Roman, E.; Miller, E.; Harmsen, A.; Wiley, J.; Von Andrian, U.H.; Huston, G.; Swain, S.L. J. Exp. Med., 2002, 196(7), 957-68,

[67] Felli, M.P.; Maroder, M.; Mitsiadis, T.A.; Campese, A.F.; Bellavia, D.; Vacca, A.; Mann, R.S.; Frati, L.; Lendahl, U.; Gulino, A.; Screpanti, I. Int. Immunol., 1999, 11(7), 1017-25.

[68] Trama, J.; Go, W.Y.; Ho, S.N. J. Immunol., 2002, 169(10), $5477-$ 88 .

[69] Chojnacki, A.; Shimazaki, T.; Gregg, C.; Weinmaster, G.; Weiss, S. J. Neurosci., 2003, 23(5), 1730-41.

[70] McLoughlin, R.M.; Jenkins, B.J.; Grail, D.; Williams, A.S.; Fielding, C.A.; Parker, C.R.; Ernst, M.; Topley, N.; Jones, S.A. Proc. Natl. Acad. Sci. USA, 2005, 102(27), 9589-94.

[71] Ernst, M.; Inglese, M.; Waring, P.; Campbell, I.K.; Bao, S.; Clay, F.J.; Alexander, W.S.; Wicks, I.P.; Tarlinton, D.M.; Novak, U.; Heath, J.K.; Dunn, A.R. J. Exp. Med., 2001, 194(2), 189-203.

[72] Atsumi, T.; Ishihara, K.; Kamimura, D.; Ikushima, H.; Ohtani, T.; Hirota, S.; Kobayashi, H.; Park, S.J.; Saeki, Y.; Kitamura, Y.; Hirano, T. J. Exp. Med., 2002, 196(7), 979-90.

[73] Rose-John, S.; Scheller, J.; Elson, G.; Jones, S.A. J. Leukoc. Biol., 2006, $80(2), 227-36$

[74] Weiss, T.W.; Kvakan, H.; Kaun, C.; Zorn, G.; Speidl, W.S.; Pfaffenberger, S.; Maurer, G.; Huber, K.; Wojta, J. J. Mol. Cell Cardiol., 2005, 39(3), 545-51. 
[75] Hirota, H.; Chen, J.; Betz, U.A.; Rajewsky, K.; Gu, Y.; Ross, J., Jr.; Muller, W.; Chien, K.R. Cell, 1999, 97(2), 189-98.

[76] Gaussin, V.; Tomlinson, J.E.; Depre, C.; Engelhardt, S.; Antos, C.L.; Takagi, G.; Hein, L.; Topper, J.N.; Liggett, S.B.; Olson, E.N.; Lohse, M.J.; Vatner, S.F.; Vatner, D.E. Circulation, 2003, 108(23), 2926-33.

[77] Fedak, P.W.; Moravec, C.S.; McCarthy, P.M.; Altamentova, S.M.; Wong, A.P.; Skrtic, M.; Verma, S.; Weisel, R.D.; Li, R.K. Circulation, 2006, 113(2), 238-45.
[78] Gene Ontology Home. Generic GO Slim. http://www.geneonto logy.org/GO.slims.shtml (accessed November 20, 2006).

[79] McCarthy, F.M.; Wang, N.; Magee, G.B.; Nanduri, B.; Lawrence, M.L.; Camon, E.B.; Barrell, D.G.; Hill, D.P.; Dolan, M.E.; Williams, W.P.; Luthe, D.S.; Bridges, S.M.; Burgess, S.C. BMC Genomics, 2006, 7, 229. 